\title{
Den sproglige udvikling i Sønderjylland efter Genforeningen
}

af Magda Nyberg

Sønderjyllands (Nordslesvigs) genforening med Danmark i 1920 blev en begivenhed, der medførte forandringer inden for alle områder af samfundslivet, forandringer, som også blev mærkbare for den enkelte borger. Der kom forandringer inden for retsvæsen og administration, inden for kirke- og skoleområdet og inden for kulturlivet $\mathrm{i}$ det hele taget. I denne forandringsproces kom sproget til at spille en vigtig rolle, idet det officielle sprog ved Genforeningen ændredes fra tysk til dansk. Indførelsen af dansk sprog blev udadtil det mest markante udtryk for de ændrede forhold.

Hvad dette kom til at betyde for sprogforholdene i Sønderjylland, vil jeg prøve at belyse $\mathrm{i}$ det følgende. Men først skal den sproglige situation op til Genforeningen kort opridses.

\section{Den sproglige situation op til Genforeningen}

Indtil 1920 var Sønderjylland under tysk styre, og fra 1876 blev dansk efterhånden trængt ud som rets- og forvaltningssprog. Skolesproget blev tysk fra 1888, og selv om dansk vedblev at være kirkens hovedsprog, blev der gradvist indført flere tyske gudstjenester. Den germaniseringsproces, der herigennem blev sat i gang, måtte fremkalde stærke reaktioner i et område, hvor indbyggerne talte dansk, nærmere betegnet sønderjysk. Hvordan situationen oplevedes, har to fremtrædende sønderjyder, Gustav Johannsen og H.P. Hanssen-Nørremølle, givet udtryk for.

I Sønderjyske Årbøger $1890^{1}$ skriver Gustav Johannsen med udgangspunkt i omtalen af skoleordningen af 1888: „I Året 1889 joges det danske Sprog, Nordslesvigernes Modersmål, så godt som fuldstændigt ud af Almueskolen, og derfor mærkes dette År med en særlig sort Rand på Nordslesvigs Tidstavle. Men som hidtil ville de nordslesvigske Mødre også i Fremtiden lære deres små at bede deres Fadervor i Hjertesproget og at synge Lovsange og Fædrelandssange i Modersmålet. Og Mændene ville, om end ikke på Thinge, hvor det danske Sprog er forbudt, ved folkelige Sammenkomster og ved Folkemøder 
uforsagt svinge Åndens Sværd i Modersmålets kraftige og til Hjertet trængende Toner.«

Og H.P. Hanssen-Nørremølle skriver ${ }^{2}$ med udgangspunkt i de kirkelige forhold: "De faktiske Magtforhold vil også i denne Henseende foreløbig bestemme Udviklingens Gang, men den nordslesvigske Befolkning vil derved få Lejlighed til at høste Erfaringer, som kan blive af stor Betydning for Fremtiden. Erfaringer som den, at vi trods al kirkelig Repræsentation er ligeså værgeløse, når man vil trænge vort Modersmål ud af Kirken, som da man trængte det ud af Skolen, vil nemlig forberede et fuldstændigt Brud med Statskirken. Og hvis Udviklingen som det er at vente, fortsættes i det begyndte Spor, vil det snart nå så vidt, at en almindelig Udtrædelse af Statskirken må tilstræbes, ikke blot af nationale men også af kirkelige Grunde.« De to citater giver et godt indtryk af holdningen til den sprogpolitik, der førtes fra tysk side.

Eftersom tysk altså på det officielle plan blev så godt som eneherskende, var tosprogethed $i$ et vist omfang en nødvendighed. Men ikke desto mindre blev netop germaniseringsbestræbelserne den faktor, der altså paradoksalt nok blev motivationen for at holde fast ved det danske/sønderjyske sprog (jf. citaterne ovf.).

\section{Folkesproget}

Det sprog, man talte mand og mand imellem i Sønderjylland før Genforeningen var dansk. Og det, man forstod ved dansk sprog, var først og fremmest sønderjysk dialekt, som taltes ikke blot af alle dansksindede, men også af tysksindede landboer. I købstæderne var tysk fremherskende hos de tysksindede.

For de dansksindede spillede sønderjysken imidlertid en helt anden rolle end for de tysksindede, idet sproget her stod som udtryk for deres dansk-nationale tilhørsforhold og dermed også som udtryk for deres modstand mod alt tysk. Og netop det forhold, at sønderjysk spillede en så vigtig rolle i den nationale kamp gjorde, at alle i Sønderjylland talte dialekt, uanset hvilken socialklasse man tilhørte, »Og således gik det til, at den sønderjyske dialekt af dens bærere foltes mere som et sprog end som en dialekt «. $^{3}$

Men desuden er der også den omstændighed at tage i betragtning, at kendskabet til dansk rigssprog - af let forklarlige grunde - var overordentligt ringe før 1920. Kendskabet til rigsdansk indskrænkede sig i al væsentlighed til det skrevne sprog $\mathrm{i}$ form af publikationer $\mathrm{i}$ den dansk-slesvigske presse, f.eks. Flensborg Avis og Sprogforeningens Almanak. Desuden spillede Sprogforeningens mange biblioteker rundt om i Nordslesvig en afgørende rolle for kendska- 
bet til dansk sprog og kultur. ${ }^{4}$ M.h.t. kendskab til det talte rigssprog stod det dårligere til, for ganske vist kom adskillige sønderjyder allerede før Genforeningen på høj- og efterskoleophold i Danmark, men det var næppe i et omfang, der kunne spille nogen væsentlig rolle for kendskab til talt rigsmål i den sønderjyske landsdel. Da altså påvirkningen fra dansk rigssprog var minimal og modsætningen til højtysk var maksimal, er det indlysende, at dialekten i Sønderjylland opnåede en helt anden status i folks bevidsthed, end tilfældet var med dialekterne i de øvrige danske landsdele, hvor en tilsvarende politisknational modsætning til et overordnet kultursprog ikke gjorde sig gældende.

\section{De sønderjyske dialekter}

Dialekterne i Sønderjylland har fra tidlig tid haft forskernes interesse. Man whar drevet sprogstudier, ikke for sprogets egen skyld, men paa grund af dets nationale, dets historiske beviskraft ${ }^{5}{ }^{5}$ Det gælder forskere som Werlauff, ${ }^{6}$ C. F. Allen, ${ }^{7}$ E. Hagerup, ${ }^{8}$ J. Kok. ${ }^{9}$ Men selv om formålet med undersøgelserne var mere nationalt end sprogligt, forhindrer det ikke, at de nævnte værker indeholder regulære oplysninger om de sønderjyske dialekter.

Undersøgelser af sønderjysk for sprogets egen skyld indledtes i midten af 1800-tallet af K. J. Lyngby, der var den første, der optegnede dialekt i egentlig lydskrift. Den vigtigste bidragyder til indsamling af sønderjysk sprog- og kulturstof blev dog H.F. Feilberg (1831-1921). Han kom fra syvårsalderen til at bo i Vester Vedsted, hvor hans fader blev præst, og fik således fra sin barndom et godt kendskab til den nordvestsønderjyske dialekt. Han kom i det hele taget til at tilbringe en stor del af sit liv i sønderjysktalende områder, idet han som ung teolog blev ansat som kapellan hos Hagerup i Angel; derefter blev han præst i Valsbøl, senere i Store Vi i Sydslesvig, og han sluttede i et embede i Darum lidt nord for Ribe. Sin interesse for sønderjysk sprog og kultur bevarede han livet igennem, og i hans store ordbogsværk: Bidrag til ordbog over de jyske almuesmål (1866-1914) indgår det sønderjyske stof med stor vægt. Også forskere som Nikolaj Andersen, P.K. Thorsen og Marius Kristensen mfl. har ydet vigtige bidrag til udforskningen af de sønderjyske dialekter. Men for alle de nævnte sprogforskere gælder det, at det var dem om at gøre kraftigt at fremhæve, at sønderjysk var en dansk dialekt - ikke et blandingssprog, hvor de fleste elementer var tyske, som det hævdedes blandt adskillige tyske sprogforskere.

At mængden af tyske indslag i det sønderjyske ordforråd var stor, kan ikke nægtes; den var langt større end i dansk i almindelighed, hvor man skønsmæssigt regner med, at ca. 1/3 af ordforrådet består af lån fra middelalderligt høj- 
og nedertysk. Mange af de låneord, som findes i sønderjysk, kom ind via forvaltnings-, kirke- og skolesproget, men tyske betegnelser, som hører til inden for en række andre sagområder, træffes også. Det konstaterede jeg, da jeg for nogle år siden beskæftigede mig med tyske lån i sønderjysk. ${ }^{10}$ Betegnelser inden for områder som: byggeskik, landbrugsredskaber, håndværkerredskaber husgeråd, mad og drikke, beklædning, mønt, mål og vægt, leg og spil, sygdomme, personbetegnelser, dyre- og plantenavne vandt også indpas. Men disse lån medfører naturligvis ikke, at sønderjysk holder op med at være en dansk dialekt. De tyske låneord førte jo ikke til ændringer i dialektens lydlige og grammatiske system.

Efter Genforeningen fortsatte forskernes interesse for sønderjysk, også for de danske dialekter syd for 1920-grænsen. Et kolossalt optegnelses- og indsamlingsarbejde gik i gang, og det indsamlede materiale blev udnyttet til beskrivelse af de sønderjyske dialekter både lydligt, grammatisk og ordforrådsmæssigt. Så snart det blev teknisk muligt, begyndte man at lave lydoptagelser, først på fonografvalser, derefter på grammofonplader og bånd. Således er de allerfleste sønderjyske sogne repræsenteret i Institut for dansk Dialektforsknings båndarkiv, et materiale, der er vigtigt, når man vil sammenligne sønderjysken før og nu. Man må nok sige, at de sønderjyske dialekter hører til blandt de bedst beskrevne inden for det danske dialektområde.

Kendskabet til sønderjysk dialekt med de karakteristiske træk, som den indeholder, er baseret på sproget hos folk, som for størstedelens vedkommende

\section{Kort 1}

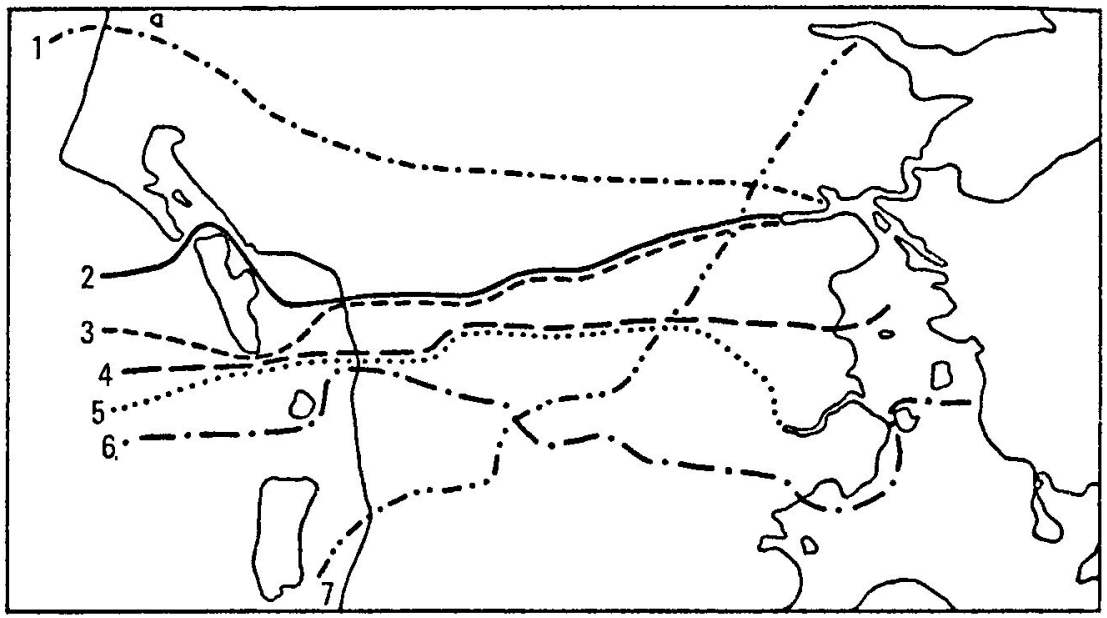

Kort over granseområdet mellem norre-og sønderjysk. Fra Peter Skautrup: Det danske sprogs historie, bd. IV, s. 120,1968 . 
er født i sidste halvdel af 1800-tallet og begyndelsen af 1900-tallet. Det sprog, vi møder hos disse sprogbrugere, er det, der forstås ved »klassisk« sønderjysk, og det var den sprogtilstand, der var herskende op til Genforeningen.

\section{Afgrænsning af sønderjysk over for nørrejysk}

De sønderjyske dialekter adskiller sig fra de tilgrænsende nørrejyske i en række tilfæelde. På kort 1 er der afbildet hele 7 grænselinier for sådanne sproglige forskelle. Det drejer sig altså ikke om en brat overgang mellem nørrejysk og sønderjysk, men om et bredt grænsebælte, som danner et overgangsområde mellem dialekterne nord og syd herfor.

Grænselinje 1 angiver grænsen mellem udtalen af hv- og hj-ord. I nord høres h'et (hjam' ('angiver stød) (hjem), hva (hvad)), i syd høres h'et ikke (jam', $v a)$.

Grænselinje 2 viser, at ordet efter i nord udtales a'ter, i syd atter/a'ter.

Grænselinje 3 danner skel mellem udtalen af $-b,-d$ og $-g$. i ord som købe, uden, kage. I nord udtales ordene som kø:v (: angiver længde), uden ( $d$ angiver blødt d), ka:g ( $g$ angiver blødt $g$ ), i syd som ko:f, uren, ka:ch (ch angiver en lyd svarende til tysk ich/ach-lyd).

Grænselinje 4 viser grænsen mellem udtalen af ord, der indeholder langt e, $ø$, og o. I nord udtales de som ie, ye, ue (si'en (sen), hy'e (hø), gu'e (god)), i syd som ei, $\sigma y$ og ou (altså med en glidning fra $e \bmod i$, fra $ø \bmod y$, fra $o$ $\bmod u$ ).

Grænselinje 5 danner skel mellem udtalen af langt å, i nord udtales det som $o$ i f.eks. go's (gås), i syd som $a$. Samme grænse følger udtalen af langt a, der i nord udtales som $a ̊$ i f.eks. $k a ̊ l l ~(k a r l)$, i syd som $a$.

Grænselinje 6 angiver grænsen for brugen af $a$ (jeg) og $a$, i nord $a$, i syd $a$.

Grænselinje 7 markerer grænsen mellem et og to køn i navneordene, i nord hedder det en mand, en barn, i syd en mand, et barn. Dette gælder også for Rømø (her er grænselinjen på kortet ukorrekt, grænselinjen skulle have gået nord om Rømø).

\section{Oversigt over de sønderjyske dialektområder}

Hvad Sønderjylland angår, kan området opdeles i flere dialektområder, et vestligt og et østligt. Desuden er der både i øst og vest forskelle mellem nord og syd, og endelig udgør Als et dialektområde for sig.

På kort 2 kan man se, at der går sproggrænser både i øst-vestlig og nordsydlig retning. 
Kort 2

Stød i HUS. GRRD, KO 0.5.V.

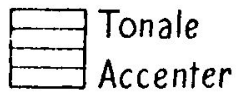

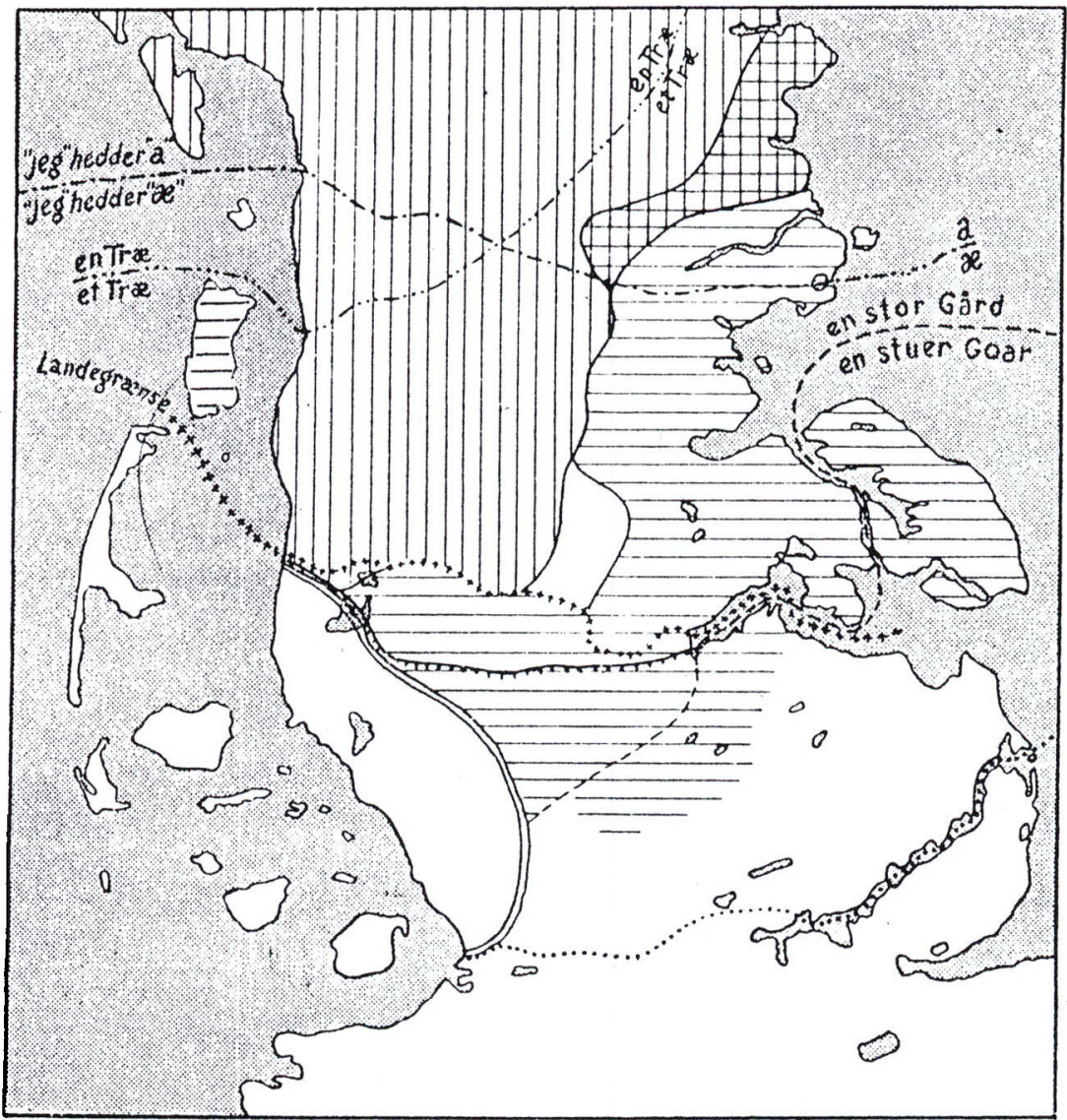

m.r. Omtrentlige Sydgranse f alm.dansk Omgangssprog nu.

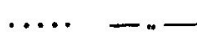




\section{Den vestlige del}

Hvis vi starter med at se på den vestlige del af Sønderjylland, kan man på kortet konstatere, at man i den nordligste del siger $a$ om sig selv, i resten af området bruges $\alpha$. I den nordligste del er der kun ét køn i navneordene, det hedder således en mand, en hus (som det kendes på vestjysk). I resten af området har vi to køn, intetkøn og fælleskøn, som i rigssproget. I hele det vestlige område har vi stød som i det øvrige Jylland, men i et nordligt område (ikke angivet på kortet) har vi yderligere - som på vestjysk - stød i ord som: takke, banke (ta'k, ban'k).

Hvad der ikke kan aflæses af kortet er følgende: i et midterområde, strækkende sig fra Skærbæk i nord til Højer i syd, optræder der det, der med en faglig betegnelse kaldes klusilspring, det vil sige en særlig udtale af enstavelsesord, der indeholder langt $i, y, u$. Således udtales is som idjes, by som bydj, hus som huges. Konsonanten $b$ udtales i ord som købe som $f(k a: f)$, men i nutidsformen køber udtales det som $v$ (kø:ve). Konsonanten $g$ udtales i ordet bage som $c h$ ( $b a^{\prime} c h$ ), i nutidsformen bager udtales g'et som blødt $g$ (ba:ge). Disse konsonantudtaler gælder for hele området undtagen en lille stribe nær grænsen, hvor udtalen i alle tilfælde er $f$ og $c h$.

\section{Den østlige del}

Specielt for den østlige del er det, at stødet mangler i størstedelen af området. Her har vi tonal/musikalsk accent. Ved tonal accent forstås den særlige tonegang, der findes i henholdsvis enstavelses- og tostavelsesord. Sammenligner vi for eksempel udtalen af ordet hus (ental) med udtalen af huse (flertal), kan der høres to forskellige tonale forløb. I et lille nordøstligt område forekommer stødet, men her kombineret med den tonale accent. Endelig findes der et lille område omkring Tinglev, hvor der hverken er stød eller tonal accent.

Som $\mathrm{i}$ vest findes der også $\mathrm{i}$ øst et nordligt område, hvor man siger $a$ om sig selv, mens man i resten af området bruger $a$. Der er i hele området 2 køn i navneordene, fælleskøn og intetkøn.

Som $\mathrm{i}$ vest findes der også $\mathrm{i}$ øst et nordligt område, hvor konsonanterne $\mathrm{b}$ og g udtales som henholdsvis $f / v$ og $\mathrm{ch}$ (blødt) $g$ efter de samme regler som omtalt ovenfor. Men $\mathrm{i}$ øst ligger grænsen for det område, hvor udtalen i alle tilfælde er $f$ og $c h$, langt nordligere end i vest, den følger en linie, der går fra lidt vest for Tønder til Åbenrå.

Als

Som allerede nævnt adskiller de alsiske dialekter sig fra dialekterne på fastlandet på en række punkter, men generelt kan man sige, at de står den sydøstsøn- 
derjyske dialekt nær. Man siger $\alpha$ om sig selv. Der er to køn i navneordene. Der høres tonal accent.

Afvigende fra fastlandssønderjysk som helhed er det, at de lange vokaler $e$, $o, o$ på Als udtales som tvelydene/diftongerne ie, ye, ue eller som $i:, y:$ : u:, mens de på fastlandet udtales som $e i, ø y, o u$. På alsisk udtales således ordet sen: sien eller si:n, på fastlandssønderjysk sein, ordet hø udtales på alsisk hye eller $h y$ :, på fastlandssønderjysk høy, ordet god udtales på alsisk gue eller gu:; på fastlandssønderjysk gou. Også udtalen af langt æ og å afviger i en række tilfæelde fra udtalen på fastlandet, idet $a$ : udtales som $e a$, $\stackrel{a}{a}$ : som $o a$. Der er i det hele taget mange variationer m.h.t. vokaludtaler sognene imellem, hvilket fremgår af Ella Jensens redegørelse $i$ afhandlingen: De lange Vokaler i Alsisk, Danske Folkemaal 1979, s. 41-54.

\section{Bydialekterne}

Specielt for det sønderjyske område er, at man har haft særlige bydialekter. Således havde Haderslev, Åbenrå og Tønder hver sit bysprog. Bysprogene er karakteristiske ved, at de dels har træk til fælles med de omgivende landdialekter, dels har træk, der ikke genfindes i de omgivende dialekter. Byboerne har nok haft trang til også gennem sproget at distancere sig fra landboerne, en reaktion, der findes udmøntet i talemåden: a bynne fra a la:n ma a katfåsta:n (bønderne fra landet med katteforstanden). ${ }^{11}$ Desværre er bysprogene ikke beskrevet i samme omfang som dialekterne. Man mener dog at vide, at nogle træk var fælles for bysprogene. I modsætning til landdialekterne, der havde fortunge-r (som i engelsk), havde man $\mathrm{i}$ bysprogene bagtunge- $r$ (som i rigsdansk). I bysprogene havde man kun én $n$-lyd og én l-lyd. Ordene mand og tran, knald og tal udtales som i rigsdansk, mens man i dialekterne i ordene mand og knald havde et $n$ og et $l$ med $j$-klang. Udtalen af lydforbindelserne $e j$, aj faldt sammen i $a j$, således at ordene veje og vaje lød ens. ${ }^{12} \mathrm{Om}$ der skulle være tale om flere fællestræk for bysprogene, ved vi ikke, og vi kan heller ikke få det at vide, da bysprogene allerede $i$ 1940 'erne var stærkt på retur. ${ }^{13}$ Det bysprog, vi ved mest om, er sproget i Åbenrå, som Karen Marie Olsen, der selv var født og opvokset i Åbenrå, skrev en afhandling om i 1949. Det specielt ejendommelige for åbenråsk var, at der foran $w$ kun optrådte én vokal, nemlig $a$, hvad der involverede, at ordene: lag, lov, løv, lav (tillægsord), lev (bydemåde af leve) alle udtaltes law, samt at ordene lyve, syv, tyv (mfl.) udtales lu:, sju, tju. Om Tøndersproget ved vi, at det havde en særlig udtale af $a$-lyden, således udtaltes ordet å (dvs. på) åw', tå udtaltes tåw', bar (datid af bære) bå $w^{\prime} r^{14}$

Hermed skulle sprogtilstanden op til 1920 være opridset. 


\section{Den sproglige situation efter Genforeningen}

Det officielle sprog blev efter 1920 dansk. Som rets- og forvaltningssprog indførtes dansk ved lov af 28.juni 1920. Man tog dog rimeligt hensyn til den tysksindede befolkning. "Således åbnede loven mulighed for, at såvel parter og vidner som syns- og skønsmænd, der ikke beherskede det danske sprog, ved domstolene kunne benytte sig af det tyske sprog både skriftligt og mundtligt. Retsforhandlingerne skulle i så tilfælde foregå under medvirken af en særlig tilkaldt tolk, med mindre de øvrige implicerede erklærede, at de var tilstrækkeligt tyskkyndige ${ }^{15}$

Med hensyn til kirkesproget blev det ved kongelig anordning fra august 1921 fastslået, at kirkesproget i Nordslesvig skulle være dansk, samt at kirkebøgerne skulle føres på dansk. Men som det gjaldt inden for retsvæsen og administration, åbnedes der også inden for kirken mulighed for anvendelse af tysk sprog efter nærmere fastsatte regler.

Bestemmelser for skolesproget fremkom i skoleloven for de sønderjyske landsdele af 30 .juni 1920 . Undervisningssproget skulle som hovedregel være dansk. Også inden for skolelovgivningen blev der taget hensyn til mindretallets sprog, således at der blev mulighed for at tysk kunne anvendes som undervisningssprog efter nærmere fastsatte regler.

Disse ordninger medførte, at der kom tilflyttere nordfra til Sønderjylland, idet de nyopslåede embeder inden for administration, kirke og skole i stort omfang blev besat af folk, der kom fra det øvrige Danmark. De var uddannet der, og deres sprog var rigsdansk. De kom sammen med deres familier til at udgøre en gruppe, hvis sprog blev en vigtig faktor for den sproglige udvikling i området. Selvfølgelig kom der også tilflyttere af andre kategorier, som sammen med embedsmændene tilførte området nye sproglige påvirkninger. I tidens løb kom også radioen til at spille en rolle. Ved at lytte til Danmarks Radio kom alle efterhånden til dagligt at høre talt rigsdansk.

Men den vigtigste påvirkningsfaktor blev dog skolen. Her kom alle børn til at stifte bekendtskab med rigsdansk både mundtligt og skriftligt. Og her kunne man ikke nøjes med blot passivt at lytte til rigsdansk, man skulle lære aktivt at formulere sig på dette sprog. Det er klart, at indstillingen til rigsdansk blandt de dansksindede sønderjyder, eller til hojdansk, som det hedder på sønderjysk, var en ganske anden end til højtysk. Man var ikke i opposition til rigsdansk, således som man før havde været det til højtysk. Men selv om holdningen til rigsdansk var absolut positiv, medførte det imidlertid ikke, at man aflagde dialekten. Man glemte ikke den rolle, som dialekten havde spillet i den nationale kamp; det sønderjyske sprog indgik som en vigtig del i sønderjydernes personlige identitet. Derfor fik rigsdansk heller ikke så stærk en ind- 
flydelse på dialekten, som man kunne have ventet. Langt de fleste fortsatte med at tale dialekten; rigsdansk tilegnede man sig som sit sprog nr. 2. Kun for de færreste blev der tale om et egentligt sprogskift, man blev $i$ en vis forstand ved med at være tosproget som før Genforeningen.

\section{Sproget i skolen}

Det første spørgsmål, der melder sig i forbindelse med indførelsen af dansk som undervisningssprog, og med dansk mentes der rigsdansk, er: Hvordan kunne man fra lærerside leve op til dette krav? De lærere, der havde undervist før 1920, var jo alle tysk uddannede, og deres kendskab til dansk rigssprog var minimalt.

Det vil her være relevant at se på, hvordan skoleforholdene tegnede sig umiddelbart efter våbenstilstanden i 1918. Dette ved man noget om, fordi Skoleforeningen gennem et rundspørge blandt sine tillidsmænd erfarede, at der i mange kommuner herskede opløsning i skoleforholdene. Mange lærere var faldet i krigen. Og det lærerkorps, der var tilbage, havde ikke noget enhedspræg ud over, at de var tysk uddannede. Der var dels de lærere, der var sendt til Nordslesvig fra Tyskland, dels de hjemmehørende, der var tysksindede, og endelig de hjemmehørende, der var dansksindede. Om de to første kategoriers reaktion på de ændrede skoleforhold efter våbenstilstanden oplyser L. S. Ravn ${ }^{16} \mathrm{i}$ en undersegelse fra 1963: „De preussiske skolemyndigheder havde »beauftragt « adskillige unge lærere, der intet kendskab havde til de særlige forhold i grænseegnene, med et embede i Nordslesvig. At de efter sammenbruddet 1918 hurtigt forlod landsdelen er indlysende, og for de lærere, der før eller under krigen havde udvist danskfjendtlig holdning, var der heller intet valg. Andre følte det tunge $\mathrm{i}$ at forlade hjemstavnen ..., men mente, det måtte være deres "verdammte Pflicht und Schuldigkeit« at tage sydpå og dele kår med det folk, som de ikke ville svigte«. Der var således opstået en akut lærermangel i området. For at skaffe lærerkræfter henvendte skolekredsene sig til Skoleforeningen, der så etablerede kontakt med lærere nordfra, der havde meldt sig til tjeneste i grænselandet. Allerede i årene 1918-20 kom der lærere nordfra til de sønderjyske skoler. ${ }^{17}$

Den resterende gruppe af lærere, der valgte at fortsætte arbejdet i de skoler, hvor de hidtil havde fungeret, var af gode grunde alle tysk uddannede. Og med deres kundskaber i faget dansk stod det kun sløjt til. Ganske vist havde de af dem, der på seminariet havde deltaget i de to ugentlige dansktimer, i deres eksamensbevis fået påført bemærkningen: »Befähigt zum Unterrichten im Dänischen «, ${ }^{18}$ men dette var i høj grad en sandhed med modifikationer, 
for det betød egentlig blot, at de pågældende var i stand til at give religionsundervisning på dansk, hvilket før 1920 havde drejet sig om fire timer ugentlig. Der rejstes da også fra lærerside krav om kursus i dansk. Allerede fra 1919 oprettedes der 1-3 måneders danskkurser på Lærerhøjskolen i København. Kurserne fortsatte de følgende år, ligesom der også ved Silkeborg Seminarium blev etableret danskkurser. Her er det værd at lægge mærke til, at kongelig skuespiller Peter William Jerndorff, hvis sprog i samtiden ansås for forbilledligt, var at finde blandt lærerne. Man må formode, at hans sprog også skulle være forbilledet for det undervisningssprog, som lærerne skulle benytte i skolen. Man må sige, at det ikke var små krav, man stillede til lærernes sproglige formåen. Det forekommer mig også at være en forfejlet intention, al den stund en lærer jo ikke skal optræde som en skuespiller for et publikum, men som formidler af viden til skolebørn. Under alle omstændigheder har kravet om rigsdansk som undervisningssprog, selv på et mindre ambitiøst niveau, været svært for de tyskuddannede at leve op til.

Samtidig med den nye skolelovs ikrafttræden blev alle tidligere lærere afskediget, idet man ønskede, at befolkningen kunne være frit stillet i valg af lærer. Alle stillinger blev opslået $\mathrm{i}$ juli 1920, og i oktober samme år modtog 600 lærere kaldsbrev. Heraf var 350 nordfra kommende lærere med dansk uddannelse, 250 var hjemmehørende i Sønderjylland og altså tysk uddannede. Talmæssigt udgjorde de sidstnævnte en ikke ubetydelig gruppe, og mange af dem fik en lang tjenesteperiode. Pr. 31.12.1962 var endnu 13 i embede, mens 39 var døde, 57 levede da som pensionister, mens 22 var udgået af lærerfortegnelsen i $1946 .{ }^{19}$

For disse læreres vedkommende kan rigsdansktilegnelsen i begyndelsen af deres embedsperiode næppe være nået særlig langt. Man må gå ud fra, at deres undervisningssprog har været temmelig dialektnært. Det har næppe afveget meget fra elevernes dagligsprog, undtagen m.h.t. ordforrådet. Men der, hvor dansk uddannede lærere blev ansat, kom børnene ud for et dansk sprog, der var anderledes end det sprog, de var opvokset med. Der opstod således en ny form for tosprogethed, idet børnene måtte vænne sig til at kunne betjene sig af både rigsdansk og sønderjysk. Sønderjysk talte man uden for skolen og naturligvis i frikvartererne på skolen, men i klassen var det rigsdansk - eller rettere: bestræbelserne fra skolens side gik ud på, at det skulle være rigsdansk. Det nye sprog, de nu skulle tilegne sig, lå dog deres hjemmesprog nærmere både m.h.t. ordforråd, grammatik og sætningskonstruktion, end tysk tidligere havde gjort. Selv om den rigsdanske udtale afveg fra dialektens, må rigsdansken alligevel have forekommet dem mere hjemlig. Man indså også, således som man tidligere nødtvunget havde gjort det m.h.t. højtysk, at kendskab til et overordnet sprog var nødvendigt, hvis man ville have en højere uddannelse, 
eller hvis man tænkte på at forlade området for at søge arbejde andetsteds i Danmark. Rigsdansk opnåede således en betydelig prestige - $\mathrm{i}$ hvert fald når det gjaldt det mere officielle plan.

Derimod kom rigsdansk ikke til at øve nogen særlig indflydelse på de tysksindede børns sprogsituation. For de flestes vedkommende blev undervisningssproget ved med at være tysk takket være særbestemmelserne for mindretallet i den nye skoleordning. Følgen af dette blev, at de tysksindede - og det gjaldt for øvrigt både forældre og børn - blev den gruppe, som bedst holdt fast ved sønderjysk dialekt i den klassiske form.

\section{Hvilke ændringer medførte den nye sprogsituation i dialekten?}

Kilder til viden om, hvordan dialekten udviklede sig efter Genforeningen findes spredt rundt om i mange forskellige afhandlinger og artikler, som findes opført på en litteraturliste i slutningen af artiklen. Jeg har bygget dels på disse kilder, dels på de erfaringer, som jeg har gjort i forbindelse med optegnelser og båndoptagelser $\mathrm{i}$ området.

Når jeg i det følgende taler om sproglige ændringer inden for ordforråd, udtale og bøjning, er der naturligvis ikke tale om forandringer, der skete fra den ene dag til den anden, men om forandringer, som slog igennem over en kortere eller længere årrække. Generelt om ændringerne kan man sige, at de er gennemført i de yngre generationer, mens de gamle betegnelser, udtaler og bøjningsformer undertiden stadig kan forekomme i de ældre og ældste generationers sprog.

\section{Endringer $i$ ordforrådet}

Den sproglige reaktion på Genforeningen gav sig først og fremmest udslag i, at der påbegyndtes en udskiftning af en række tyske ord med danske. Det gjaldt især m.h.t. de tyske betegnelser, der var knyttet til administration, kirke og skole. Således udskiftedes f.eks. ord som amtsret (efter tysk Amtsgericht) med dommerkontor, amtsrichter med dommer, armhus med fattighus, schaffner med konduktor, döpschien (Taufschein) med dåbsattest, aufsatz med stil, pause med frikvarter, zeugnis med karakterbog. Her foregik udskiftningen antagelig temmelig hurtigt af rent praktiske grunde. Men også ord, som hører hjemme i det almindelige ordforråd, blev i den følgende tid udskiftet, således ausbund med slovster, gavtyv, blindemumme med blindebuk, bakker med bager, dakkel med lagg, fikkedug med lommetorklade, foervark med vogn, køretøj, foermand med vognmand, geburtsdag med fodselsdag, (det er mig ikke) gelegen med (det er mig ikke) tilpas, gesigt med ansigt, isskolle med iskosse, -flage, kådner med 
husmand, lejder (udtalt laee) med stige, mantel med frakke, marmel med lobbes (kugler til kuglespil), poppe med dukke, snejdig med flot, spidsbub med kaltring, viks med skosvarte, og mange flere kunne nævnes. For disse ords vedkommende foregik udskiftningen nok langsommere end for de ovenfor næunte.

At det tyske ordstof - $\mathrm{i}$ det omfang, det var let kendeligt - udgik af dialekten, må næsten betragtes som en selvfølgelighed på baggrund af holdningen til tysk i almindelighed. Således forsvandt mange ord med forstavelsen ge-, som klart signalerede tysk herkomst.

Men midt $\mathrm{i}$ denne afstandtagen til tyske indslag i sproget får hilsenen mojn (Morgen) vind $\mathrm{i}$ sejlene. Peter Jeppesen omtaler i sin bog om udviklingen $\mathrm{i}$ Løgumklostersproget, at mojn, der hører til nordligt højtysk omgangssprog, høres hos de unge (og »unge« vil her sige folk, der var unge i 1920'erne). ${ }^{20}$ Han omtaler, at mojn afløser adjøs. Han må altså have haft den opfattelse, at adjøs har været gængs som hilsen - i hvert fald i Løgumklostersproget. Om denne hilsens anvendelse i Sønderjylland i almindelighed har man desværre ingen dokumenterede oplysninger. For hilsenen mojn har Peter Jørgensen (tidligere professor i tysk ved Københavns universitet) givet en udtømmende redegørelse, såvel for udtrykkets baggrund som for brugen af det, i afhandlingen: En sønderjysk hilsen. ${ }^{21}$ Peter Jørgensen, der selv var sønderjyde, stødte for første gang på hilsenen i 1914, da han kom i den tyske realskole i Tønder. Den kendtes ikke i Brede sogn, hvor Peter Jørgensen kom fra. Men han lærte at bruge den, for den brugtes af alle elever i skolen, uanset om man var af dansk eller tysk observans. Hilsenen kan bruges både som goddag og farvel og kan anvendes på alle tider af dagen. Peter Jørgensen troede, at brugen af denne hilsen var forsvundet efter Genforeningen. Stor var derfor han forbavselse, da han på en togrejse på vej til Tønder i 1969 hørte nogle unge piger i toget bruge denne hilsen. Ved et besøg i Brede konstaterede han, at mojn var almindelig udbredt. Nu til dags anses mojn af de fleste som noget ærkesønderjysk, hvad det på en måde også er til trods for den tyske oprindelse.

Men ordforrådet ændredes også på anden vis, idet en række ord er udgået af dialekten, fordi de arbejder, som ordene var knyttet til, enten er forsvundet, eller der er indført helt andre arbejdsprocesser, hvor man ikke kan anvende de gamle betegnelser. Dette er en udvikling, som sønderjysk har fælles med dialekter i almindelighed. Som eksempler kan nævnes: (fra ølbrygning) brue (brygge), bruekedel (bryggekedel), maltbing (kasse til opbevaring af malt), maltkølle (hus, hvori malten tørres), tylle $i$ ankere (hælde øl på tønder); (fra bagning) bagehus, ilde a ovn (fyre op i den gamle murede ovn), timse, (sigte), dejne, (lægge dej), kncede (ælte), gistne (særlig måde at forbehandle brød på inden bagningen). Jeg nøjes med disse eksempler, men noget tilsvarende kunne hentes fra områder som tærskning, høst, lysestøbning, storvask, slagtning osv. 
Herudover blev ord, som føltes gammeldags, udskiftet med mere tidssvarende. Således siger de yngre f.eks. $i$ morgen tidlig, ikke $i$ morgen årle (morn a:l), begravelse, ikke arveøl (arrel), kore, ikke age, låne, ikke borge, flaske, ikke buttel, gang, ikke fremgulv, sommerfugl, ikke skurvefugl og vaske, ikke to.

Undertiden har ord ændret betydning. Saledes havde ordet del bl.a. betydningen fad, nu bruges ordet $\mathrm{i}$ denne betydning kun af et fåtal inden for den ældre generation, itte (it) betød tidligere både ikke og intet, nu betyder det altid ikke, undtagen $\mathrm{i}$ den faste vending: der er itte at gore (dvs. det er der intet at gøre ved), oldefader og oldemoder brugtes for bedstefader og bedstemoder, nu har betegnelserne samme betydning i rigsdansk. Med hensyn til ordene bås=stald, og stald=bås er der nu vaklen i betydningen; ordene bruges i flæng, snart i den ene betydning, snart i den anden.

\section{Lydlige andringer}

Lydlige ændringer kan fremkomme af forskellige grunde. Der kan for det første være tale om påvirkning fra rigsdansk, for det andet påvirkning fra tilgrænsende dialekter, og for det tredje kan der ske nyudviklinger inden for dialekten selv. De to førstnævnte faktorer er de vigtigste.

Som det første punkt kan nævnes udtalen af ord, der indeholder forbindelsen øj: bøje, drøj, fornøje, fornøjelse, nøje, højre, tøj. Disse ord udtaltes tidligere i størstedelen af Sønderjylland by:, dry:/dry', forny:, fornyels osv., nu udtales de af de fleste som på rigsdansk, men samme udtale træffer vi også i det nordøstligste hjørne af Sønderjylland. Begge dele kan havé været medvirkende til ændringen.

Som før omtalt under oversigten over de sønderjyske hoveddialekter blev $b$ og $g$ i slutningen af ord som kobe og bage udtalt som henholdsvis $f \circ g$ ch i hele området, men i nutidsformerne køber og bager, hvor $b$ og $g$ ikke står i slutningen af ordet, blev de udtalt som $v$ og blødt $g$ i et område, der mod syd strækker sig til en grænse, der går omtrent fra Tønder til Åbenrå. Syd herfor udtales $b$ og $g$ i alle tilfælde som $f$ og ch. Men Peter Jeppesen oplyser i sin behandling af sproget i Løgumkloster, ${ }^{22}$ at hos de yngre er denne regel med enkelte undtagelser opgivet, $\mathrm{i}$ stedet følger man reglerne i det sydlige område, hvor man ikke har nogen vekslen. Dette gælder dog kun for Løgumkloster by, i landområdet har man opretholdt det gamle system. Om årsagen til forskellen mellem by og land nævnes den omstændighed, at Løgumkloster havde livligt handelssamkvem med Tønder, hvor udtalen var $f$ og $c h$ i alle tilfælde. Man nærmede altså sit sprog til den nærliggende købstads norm og lagde derved afstand til landboernes sprog.

I den vestlige del af Sønderjylland findes der (if. s. 266) et område, hvor 
langt $i, y$ og $u$ i ord som is, by, hus udtales (med klusilspring) idjes, bydj, huges. Denne udtale høres nu kun hos nogle af de ældste, de yngre udtaler ordene som på rigsdansk eller som i dialekten i størstedelen af Sønderjylland.

Da jeg i 1970'erne optegnede dialekten i Emmerlev hos en mand, der var født o. 1900, var den gamle udtale helt almindelig $i$ hans sprog. Men hos hans søn derimod, der var født o. 1930, var den gået af brug. Han kunne dog i samtale med faderen godt finde på at sige huges, indrømmede han, men blandt jævnaldrende gjorde han det ikke. Han var tilsyneladende ret bevidst om dette forhold. Det var ikke tilfældet med en kone i Skærbæk, som en ældre kollega optegnede hos. Da hun spurgte hende, om hun kunne sige huges, svarede hun: "Nej sådan noget siger (udtalt sidje) vi da itte«, altså med en klusilspringsudtale i siger.

\section{Andringer inden for bøjningen}

På dette område er ændringerne få. I en række navneord er gamle flertalsformer som bi (bier), knajt (knægte), hat (hatte), kap (kæppe) blevet erstattet af former som bie, knajte, hatte, kappe, hvor endelsen -e svarer til et -er, hvilket jo - bortset fra flertalsformen bie - er en forkert endelse set med rigsdanske øjne. Men da trykløst $e$ i slutningen af et ord falder væk i dialekten, har der ikke været anden mulighed end at bruge -er i stedet for. Ord som fløde, grød, der tidligere opfattedes som flertalsord, man sagde mange flode, mange grod, opfattes nu som entalsord, der siges meget fløde, meget grød. Inden for udsagnsordene er der i en række tilfælde sket overgang fra stærk til svag bøjning, det gælder f.eks. kyse, der før bøjedes køs/kyst, nu kyst/kyst, tarske, der før bøjedes tasg/tåsg, tosgen, nu taesget, tasget. Den gamle flertalsform i bydemåde er forsvundet. Tidligere sagde man kommer ind og satter jer ned (kom ind og sæt jer ned), når man henvendte sig til flere, men til en enkelt hed det kom ind og sat dig ned. Inden for bøjningen synes ændringerne alle at gå i retning af rigsdansk.

Alt $\mathbf{i}$ alt må man sige, at det ikke er de store forandringer der er sket, når det gælder dialekternes lyd og bøjningssystemer; men de ændringer, der er sket, går næsten alle i retning af rigssproget. Det viser sig da også, når man lytter til nutidige båndoptagelser med børn, der taler sønderjysk dialekt, at deres dialekt afviger meget lidt fra tidligere generationers.

Vi har indtil nu kun beskæftiget os med den sønderjyske dialekt. Men som vi ved, findes der andre former for sprog $\mathrm{i}$ det sønderjyske område. Der findes for det første rigsdansk, for det andet findes der et blandingssprog, hvor rigsdansk og dialekt veksler. Endelig findes der for det tredje hos det tyske mindretal tysk. 


\section{Rigsdansk i Sønderjylland}

Den form for rigsdansk, jeg vil omtale i det følgende, er den, man hører hos personer, der er født og opvokset i området.

Det vil være på sin plads, før vi begynder at beskæftige os med det sønderjyske rigssprog, at præcisere, hvordan rigsdansk og dialekt kan afgrænses over for hinanden. Herom skriver Bjerrum: ${ }^{23}$ "Til Dialekterne regner vi de Sprogarter, hvis væsentligste Bestanddele ikke kan udledes af Rigssproget, men maa udledes af et ældre Sprogtrin, som også Rigssproget kan udledes af. Derimod kalder vi ikke de Sprogarter, hvis væsentligste Bestanddele kan udledes af Rigssproget, for dialekter; det drejer sig her ikke blot om forskellige Former for Slang og Argot, men også om stedpræget Udtale af Rigssproget. Rigssprogstalende er ofte tilbøjelige til at forveksle et saadant stedpræget Rigssprog med ægte Dialekt, og det kan hænde, at ogsaa dialekttalende gør sig skyldige i denne Forveksling«. Bjerrum refererer til en historie, som Aage Fjalland fortæller $\mathrm{i}$ artiklen: Vore folkemål i likvidation: ${ }^{24}$ (en studiekammerat er på besøg i Fjallands hjem i Jylland) "Han talte rigsdansk, men var ellers jysk i sin stemmeføring. Under samtalen ved bordet komplimenterede min mor ham med, at han endnu var trofast mod sit jyske mål og endnu ikke var begyndt at "snakke fint « - en ret uheldig anbragt kompliment, da manden tragtede efter at tale rigssprog, men såre forståeligt, da tonefaldet vist nok er noget af det første, man lægger mærke til«.

Et rigsdansk, der indeholder stedprægede udtaler, er også den sønderjyske form for rigsdansk. Visse træk fra dialektudtale kan spores, ligésom også tonegangen har et sønderjysk præg, men sproget kan ikke derfor karakteriseres som sønderjysk dialekt.

I 1989-90 lavede jeg en undersøgelse af unge sønderjyders tilegnelse af rigsdansk på basis af aflæsninger af de båndoptagelser, som Karen Margrethe Pedersen havde lavet i den tyske og danske skole i Tinglev. Jeg gennemgik aflæsningerne for en række udtaletræk, som jeg mente kunne afsløre sønderjysk baggrund. Det drejede sig om følgende træk: udtalen af langt $e, \sigma, o$ som $e i, a y, o u$, udtalen af $b$ som $f$ i ord som kabe, udtalen af $g$ som $c h$ i ord som bage, udtalen af $a$-lyden, der på sønderjysk udtales som dybt $a$, dvs. som $a$ 'et i rigsdansk udtale af lang. Desuden undersøgte jeg, om der forekom brug af foransat bestemt kendeord ( $a$ mand i stedet for manden), om det kunne forekomme, at man sagde $a$ om sig selv, om man kunne sige itte i stedet for $i k k e$. Det viste sig da, at de lokaltræk, der slog mest igennem, var udtalen af $e, \emptyset, o$ samt $a$. Det »flade« $a$ hørtes så godt som aldrig. Hvad de øvrige lokaltræks gennemslagskraft angår, lå de på et meget lavt niveau. ${ }^{25}$

Desuden fandtes der i elevernes rigsdansk nogle træk, som er meget udbred- 
te i jyskpræget rigsdansk uden for Sønderjylland. Det gælder f.eks. udtalen af endelsen -et $\mathrm{i}$ tillægsformer som rystet, bestemt form af navneord som huset. Her hørtes der et tydeligt $t$ i slutningen af ordet, i rigsdansk har man her det bløde $d$. Man sagde ret ofte og (udtalt $a$ ) i stedet for også. ${ }^{26}$

Da der indgik elever fra både dansk og tysk skole i undersøgelsen, kunne det være interessant at se, om der var forskel i rigsdansktilegnelsen mellem de to elevkategorier. Det viste sig, at der ikke kunne konstateres nogen forskel mellem de to gruppers rigssprogstilegnelse m.h.t. de undersøgte træk. Men en forskel mellem dem var der dog. Eleverne fra den tyske skole talte et rigsdansk, der i visse henseender minder om oplæsningssprog, idet deres udtale var meget mere distinkt end hos eleverne i den danske skole. Desuden indgik der adskillige germanismer i elevsproget i den tyske skole. Som eksempler kan nævnes udtalen af ordet altså, der udtales also (med $o$ i slutningen af ordet som på tysk), udtale af $s c h$-lyd foran $t$ i navnet Stefan, endelsen -ing kan optræde som -ung (narung), man stiller sin taske hen (stiller sin taske fra sig, tysk: hinstellen), vi snakker sønderjysk under hinanden (vi snakker sønderjysk indbyrdes, tysk: untereinander). Noget tilsvarende forekommer ikke hos elever i dansk skole.

Men til trods for at disse unge sønderjyder for de flestes vedkommende havde dialekt som hjemme- og omgangssprog, var deres rigsdansktilegnelse fuldt ud på højde med det rigsdansk, som tales af unge mennesker i Odderområdet, hvor en lignende undersøgelse er foretaget. ${ }^{27}$ Det drejer sig her om personer, der er ensprogede og kun taler et jyskpræget rigsdansk. Den jyske dialekt, der tidligere taltes på Odderegnen, høres næsten ikke mere.

Om den svagt sønderjysk-farvede form for rigsdansk af sønderjyder kan opfattes som sønderjysk, ved jeg ikke præcist, men jeg har en mistanke om, at opfattelsen i hvert fald kan forekomme, især da hvis den talende ud over den stedprægede udtale undertiden også anvender sønderjyske særgloser eller sønderjyske vendinger. Dette virker som signaler om, at den talende identificerer sig med lokalsamfundet, hvilket kan have den effekt, at sproget faktisk opfattes som sønderjysk, selv om det ligger uendelig langt derfra. Jeg har i hvert fald på optegnelses- og båndoptagelsesrejser oplevet - via sønderjyder - at blive henvist til folk, der blev karakteriseret som gode til at snakke sønderjysk, men som efter min mening slet ikke kunne betegnes som dialekttalende.

\section{Blandingssprog}

Jeg vil starte med at gengive nogle eksempler på den form for sprog, som jeg har kaldt blandingsspres. Eksemplerne er for de to førstes vedkommende hen- 
tet fra Institut for dansk Dialektforsknings båndarkiv. Den første er en optagelse fra det sydøstlige Sønderjylland, den anden fra den nordvestlige del. De to sidste er fra Karen Margrethe Pedersens optagelser med skoleelever i Tinglev. De rigsdanske passager er gengivet i almindelig retskrivning, de dialektale er skrevet med kursiv, i et vist omfang i en tillempet lydskrift.

\section{Tekst 1}

da jan af deres lejere $v a ̊ d ø j$, og der ikke fandtes en arving i den familie, og hun havde ikke disponeret på nogen vis, så de awetog (overtog) simpelthen den butik og kø vire. vi ha:j altså to butikker å køe ma og i a kolonialfårratning vå det småt med at få varer, så law (dvs. da) a kri vå awe, da lejet moe den butik ue te $\mathrm{NN}$... han lajet så a butik og så ha:j vi kun jan butik teba:ch, men den lajet NN så også, for de trængte til mere plads. I 1920 blaw (blev) den også opgien. $\mathrm{Og}$ så sat (sad) hun teba:ch ma a ajendom og lajet butikker og lejligheder ue. Det er jo en stor firelænget ejendom, dan ha - den gamle købmandsgårdstype.

a kom jo så $i$ dansk sko:l omsier. AE haj begyndt at gå $i$ tysk sko:l, la:r (lært) å sang å (på) tysk og snak å tysk og olt mu:lich. De fleste af mine klassekammerater fra den tysk sko:l, de gik med over i den danske skole, for vi var faktisk et dansk flertal i den klas. Og vi fortsatte så med ol di oplawelse, som en ny skoleform kunne medføre. Det var festligt og fornøjeligt at komme over i dansk skole, vå (hvor) vi ent (inte, dvs. ikke) vå naee så møj under kommando og alligevel var der justits og respekt for de lærere vi $f a k$.

(Indtaleren født i begyndelsen af 1900-tallet).

\section{Tekst 2}

Det var i den tyske tid, som vi si'e ha'e. Og vi kom jo i den tysk sko:l, vå vi jo stort set kun haj ynnevisning (med tryk på -visning) å tysk, bortset fra nåwe ti:me i religion. Vi kom i tysk skole, og det var jo mest ynnevisning i det tysk språch.

Men al'es gak a sko:lti sådan godt nok, og vi børn vi vajsd op som almindele børn de gør og ha:j jo bå:de (udtalte med hørligt d) gla:j daw: og daw:; da vå it (itte, dvs. ikke) så go:j, sådan som det nu falder. Men da vi kom ud $a a$ sko:l, så måtte vi jo ue å - i plasse ve a bynde, å de vå vi å (og, dvs. også), indtil den tid, te vi ku kom å en højskole. a ha vat å højskole den gang i (her retter indtalerens kone ham og siger: dangång)

(indtaleren fortsætter:) nåh ja, det er lidt lange øst på, de si (siger) gang.

Vi havde selvfølgelig her som i mange ande staje, da'e ha'e vi vo aj'nsdialekt å det for jo ma sa, at det språch, te vi ha:j, de vå jo tit, når vi kom længere væk, så ku de kni:f, at det blow forstanden (forstået); $a$ ka håws, da a va øwe 
å Sjalland,.. da vå da nåwe di kåldt a hammel og så mente de, nej-de kåldt et (dvs. det) a skagle skaglerne, og jeg troede, te det var de skagler, som vi satte ve a si å en hest, når de var jan- enspænder. Men de mente $a$ hammelreb, som vi kaldte et (det) her. Det var spand å a hammelstok. Og det var jo en (fælleskøn i stedet for intetkøn) hel anden utrøk, di ha:j for den ting, som (dvs. end) vi ande vi ha:j ho'e i Sønderjylland.

(Indtaleren født $\mathrm{i}$ begyndelsen af 1900-tallet).

\section{Tekst 3}

(interviewerspørgsmål anført i parentes)

(der tales om indkøb af en båndoptager)

Jeg har lige købt en til seks et halvt tusind og så to hunnevatshøjtalere (hundrede-wattshøjtalere) en kan lisse godt ko:f nåwe airnle nåwe med a sa:m, men det er ikke kun $a$ højta:ler det komme an å jo.

H. og mig vi geek over grænsen, og så min stoebroe han koy (kørte) i a bil bachatte (bagefter), så måt vi godt ha et ma (have det med).

(Hvad er det for et mærke?)

Det er Jamo, det er er godt, dem har jeg købt af - jeg købte nogle - va hei det $n o$.

(Kendte du dem før?)

Nej det gøy (gjorde) jeg godt nok heller ikke. det er et galt godt mark, de fak a galt bilich jo, elsen (ellers) sku det ha kost (kostet) - nej jeg gav ikke engang seks tusind, nej a gaw fie tu:sen fam hune (hundrede) for a forstarke.

(Er det bedst at bruge japanske bånd?)

Det ved jeg ikke, fordi deres båndoptagere, dem - halle de lawe $a$ bånd efter $a$ båndoptagere faktisk.

(Hvad bruger du?)

metalbånd, de er dye eno, det er mest chrom (dvs. chrombånd) $a$ hae å (dvs. også) to metalbånd no.

(Indtaleren født 1970).

\section{Tekst 4}

(Hvad laver du efter skoletid?)

Ja når $a$ kommer hjem fra skole, så lawe $a$ lektier eller nåwe ant (andet), hvis vi ikke har nåwe for. Så halv fire da skal $a$ så å arbe (arbejde). Der har jeg et eftermiddagsjob. Der passer $\alpha$ to børn. Og så gør $a$ samtidig rent.

(Hvad laver du så med de børn?)

Ja der leiche $a$ - og så lawe vi puslespil. Nu den jan (ene) er ikke så gammel. Hun er kun et halvt år. Så hende er der ikke så møj å law: $m a$.

(Hører du radio?) 
Ja det hører jeg også. Ja nåwe gange så hører jeg - der hører jeg vel lige meget tysk og dansk.

(Går du i ungdomsklub og sådan noget?)

$\mathrm{Ja}$, om manda awten går $\mathfrak{a}$ til gymnastik.

(Hvad er det mest piger eller mest drenge?)

Det er mest piger. Drengene de vil ikke så gerne. Vi har et par enkelte. Men det er lissom om de it rechte (rigtig) gie.

(Det eftermiddagsjob, har du det hver eftermiddag?)

Nej om mandagen og om tirsdag, onsdag og fredag (navnene på ugedagene er udtalt på rigsdansk, men mangler bestemthedsendelsen, på sønderjysk hedder det om tirsdag osv.). Torsdag da kan $a$ ikke, da går $a$ til gymnastik. $\mathrm{Og}$ så har $a$ også en gang imellem om aftenen, hvor der så er nåwe, der ringer og spørger om $a$ kan passe deres børn i $a$ weekend.

(Indtaleren født 1970).

Indtalerne af tekst 1 og 2 er begge født i begyndelsen af 1900-tallet, har levet stort set hele deres liv i Sønderjylland og fået deres uddannelse der. Deres opvækstsprog og daglige omgangssprog har været sønderjysk, men da begge har haft brug for at optræde i officielt regie, har de til brug her også tilegnet sig rigsdansk.

Som det fremgår af de gengivne tekster, formulerer indtalerne sig skiftevis på rigsdansk og dialekt. Det fremgår også, at de behersker begge dele.

Hvad kan være årsagen til, at de bruger snart den ene slags sprog, snart den anden? Her vil det være relevant at se på den situation, som danner baggrund for samtalen. Der er tale om en situation, hvor en udefra kommende har henvendt sig for at få en båndoptagelse med en prøve på sønderjysk. Anmodningen accepteres. Ikke desto mindre opstår der hos indtaleren en vis usikkerhed med hensyn til sprogbrug. For det første får han stillet spørgsmål på rigsdansk, og det forekommer ham måske derfor svært at svare på dialekt, eftersom han jo også behersker rigsdansk. For det andet kan han være bange for, at samtalepartneren som udefra kommende ikke helt vil forstå, hvad der bliver sagt.

Udgangspositionen er sprogligt kompliceret, og denne usikkerhed afspejler sig i den vekslende sprogbrug. At der blandes, er den talende næppe altid bevidst om. Det viser sig nemlig, at hvis han senere får lejlighed til at lytte til optagelsen, bliver han forundret over, at han ikke hele tiden har talt sønderjysk, hvad der var hans intention. Nu er der for både tekst 1 og 2 tale om udpluk af optagelser, hvor blanding optræder. Gennemgår man hele optagelsen, konstaterer man, at der ikke blandes i lige høj grad hele tiden. Hvis der fortælles en anekdote, gengives den i ublandet dialekt, mens blandingssproget kommer frem i de mere nøgternt refererende afsnit.

M.h.t. tekst 3, hvor vi oplever et lignende blandingssprog som i 1 og 2, er 
udgangssituationen en anden, idet indtaleren (en skoleelev) her forsøger at formulere sig på rigsdansk over for en rigsdansktalende samtalepartner. Samtalen finder sted i skoleregie. At indtaleren kan tale uforfalsket dialekt, er der ingen tvivl om, derimod tvivler man på, at han kan formulere sig nogenlunde korrekt på rigsdansk i længere forløb. På et spørgsmål, om han finder det vigtigt at kunne tale rigsdansk, svarer han: nej, va sku man bruch-et (bruge det) te, når man boue hernei. Indtaleren agter at blive bu'n (bonde, dvs. landmand). Med den holdning forstår man, at anstrengelserne for at tilegne sig rigsdansk ikke har været store.

Langt den størst del af samtalen foregår da også på ren dialekt.

I tekst 4 drejer det sig om en skoleelev i samtale med en sønderjysktalende interviewer. Samtalen foregår på en skole. Her møder vi et sprog, der nok er blandet, men her er dialektindslagene særdeles korte, ofte kun omfattende et enkelt eller et par ord. Kun i ét enkelt tilfælde kommer der en hel sætning på dialekt. Det hyppigste dialektindslag består $\mathrm{i}$, at der siges $a$ for jeg. Sproget $\mathrm{i}$ tekst 4 må betegnes som temmelig rigsdansknært $i$ sammenligning med de andre tekster. Der er tale om et sprog, der virker, som om det ikke har fundet sin endelige form. Det bør retfærdigvis her nævnes, at indtaleren, foruden dette sprog, kan betjene sig af et så godt som korrekt rigsdansk i samtale med en rigsdansktalende partner og desuden kan formulere sig utvungent på dialekt i samtale med en sønderjysktalende veninde. Men til en sønderjysktalende interviewer, som indtaleren ikke kender på forhånd, vælges der altså en mellemform. Det skønnes antagelig, at situationen ikke er så uformel, at dialekten kan bruges. Til gengæld takseres den ikke som så formel, at rigsdansk vil være det rigtige.

Som det fremgår af de gengivne tekster, findes der i Sønderjylland foruden rigsdansk og dialekt en række forskellige blandingsformer, strækkende sig fra noget meget dialektnært til noget ret rigsdansknært. M.h.t. de former for blandingssprog, som vi møder i tekst 1-3, må man uvilkårligt stille sig selv det spørgsmål: Kan sådanne former for sprog anvendes som omgangssprog sønderjyder imellem? Svaret må blive: Nej, det forekommer helt usandsynligt. Jeg mener, at det kun vil forekomme i situationer, hvor en ikke-sønderjysktalende er involveret. M.h.t. sproget i tekst 4 forholder det sig anderledes. For selv om sproget hos indtaleren i tekst 4 må siges at være situationsbestemt, for vi ved jo, at indtaleren kan tale både dialekt og rigsdansk, kan man sagtens forestille sig, at der kan findes personer, der som eneste sprog har en sådan blandingsform, nemlig dem, der på et tidligt tidspunkt, hvor deres sprog endnu ikke har fundet sin endelige form, er blevet påvirket i rigsdansk retning i en sådan grad, at dialekten er blevet afløst af et blandingssprog, der i mange henseender ligger rigsdansken nær, men hvor den dialektale baggrund dog slår tydeligt igennem. 
Man må snarest karakterisere denne form for blandingssprog som et trin på vejen hen imod rigsdansk. Hvorom alting er, disse former for blandingssprog hører med i billedet af den sproglige mangfoldighed i området.

\section{Tysk}

Tysk anvendes kun af det tyske mindretal. Hvordan det tyske sprog er beskaffent, når det bruges uden for den officielle sfære, ved vi meget lidt om. De oplysninger, der findes om det tyske hjemmesprog, er af gammel dato, fra omkring århundredskiftet. De stammer fra Nikolaj Andersens afhandling: Det danske sprogs indflydelse på højtysk i Nordslesvig. ${ }^{28}$ Nikolaj Andersen bygger på iagttagelser af sproget hos personer, der er opvokset med tysk som hjemmesprog. M.h.t. udtalen forekommer der adskillige afvigelser. Således udtales tysk $e i, e u$ hyppigt som $e j, \ddot{o j}$, ikke som på korrekt tysk som $a j$, åj. Lyden $z$ (ts) udtales ofte som $s$. Sch-lyden udtales undertiden som sj foran vokaler (schön udtales sjø'n). Foran konsonanterne $m, n, l, r$ udtales sch-lyden undertiden som $s$, (f.eks. udtales Schnee som sne:); står der sch i slutningen af et ord, kan der nu og da høres et $s$ i stedet for et $s c h$. Hvor man på tysk udtaler stemt $s$, høres ofte et ustemt $s$. Forbindelserne $p f$, $p s$, psch i begyndelsen af et ord udtales som $f$ og $s$. Desuden omtaler Nikolaj Andersen en lang række afvigelser inden for bøjning, afledning og sætningskonstruktion.

Jeg må nøjes med at gengive nogle få eksempler. Som genitivskonstruktioner kunne høres: mein Bruders Hut, meine Mutters Bruder; i stedet for som på korrekt tysk at sige: es friert mich, sagde man: ich friere, man sagde: das regnet ikke: es regnet. Undertiden anvendte man forkert kasus efter en præposition, f.eks.: er wohnt um der Ecke (korrekt er: um die Ecke). Ofte høres und brugt i stedet for zu: es gelang uns und kriegen ihm (skulle være ihn) abgesetzt (det lykkedes os af få ham afsat). Nikolaj Andersen anser disse afvigelser for at være influeret af dansk; men Peter Jørgensen har i Danske Folkemaal, 1930 gjort opmærksom på, at ikke alle afvigelser kan tilskrives dansk påvirkning. ${ }^{28 a}$ Også plattysk har spillet en rolle. I mange tilfælde vil det slet ikke være muligt at afgøre, om det er det ene eller det andet, der er tilfældet. Endelig, fremhæver Peter Jørgensen, er der slet ikke taget hensyn til det almindelige nordtyske omgangssprog.

Nogle af de nævnte afvigelser har også kunnet høres senere hen. En lærer ved en tysk skole fortæller på et bånd om sine oplevelser med tysk sprogfærdighed hos sine elever. Tidspunktet er 1930'erne. Det fortælles blandt andet, at eleverne havde vanskeligheder med udtalen at tysk $z$. Derfor trænede man eleverne ved at sige: Sag mal zwo, zwa, zwischen. Og børnene forsøgte sig, men det lød som swo, swa, swisjen. I det hele taget var det svært at få eleverne til 
at formulere sig på tysk. Og gjorde de det, så var det, som læreren bemærker, ikke "streifenfrei«. Da man fejrede Pestalozzis fødselsdag, udbrød en lille pige, idet hun pegede på et billede af Goethe: Ist das der, was war so gut bei die Kinder? Eller en dreng, der var på en rejse i Tyskland med skolen, gav følgende svar, da læreren spurgte ham om, hvorfor han ikke havde nattøj på: Nein Herr Lehrer, ich schlaf(e) immer in blossem Schein.

"Ja, sikken et tysk vi da snakkede« tilføjes der. Tilsvarende historier har andre også kunnet give til bedste, hvoraf man naturligvis ikke kan slutte, at mindretallets tyskfærdighed $\mathrm{i}$ almindelighed stod på dette stadium. Men at der har kunnet indsnige sig danismer og påvirkninger fra plattysk og fra nordtysk omgangssprog er jo helt naturligt.

Hvordan situationen er nu til dags ved vi ikke meget om, men de eksempler, som Karen Margrethe Pedersen gengiver, ${ }^{29}$ viser, at i hvert fald nogle af de ovenfor nævnte afvigelser stadig kan høres hos børnehavebørn i tysk børnehave og hos elever i 6. klasse i den tyske skole. Hos Karen Margrethe Pedersen ${ }^{30}$ omtales en udtaleafvigelse, som ikke er næunt hos Nikolaj Andersen, nemlig udtalen i forbindelserne $s p-$-, $s t$ - som $s p$, st, og ikke som på korrekt tysk som schp, scht. Denne udtale er almindelig i den form for tysk, der tales i grænseregionen i dag. Hvor meget man kan slutte om det tyske hjemmesprog ud fra eksempler hos skoleelever, der interviewes af en tysktalende lærer, genfortæller en historie på tysk eller instruerer en kammerat $\mathrm{i}$, hvordan man bygger en flyver af legoklodser, tør jeg ikke udtale mig om. Måske er der bare tale om begyndervanskeligheder, for $\mathrm{i}$ de fleste tilfælde er hjemmesproget ikke tysk, men sønderjysk, hvilket i så fald betyder, at børnene først har stiftet bekendtskab med tysk i institutionerne. Her tilstræber man at lære eleverne at formulere sig på korrekt højtysk, og det skulle der være gode muligheder for, da mere end halvdelen af lærerne (59\%) kommer fra Tyskland, 39\% fra Danmark. De fleste af de sidstnævnte tilhører mindretallet og har fået deres uddannelse i tysk skole og gymnasium og fortsat uddannelsen ved Pädagogische Hochschule i Flensborg. ${ }^{31}$ Elevernes sproglige baggrund er for mere end halvdelens vedkommende sønderjysk dialekt, resten har haft tysk som hjemmesprog, et tysk, der næppe i alle tilfælde lever op til den standard, som skolen kræver.

\section{Vil den sproglige mangfoldighed i Sønderjylland kunne opretholdes?}

Efter at have givet en oversigt over hvilke former for sprog, der kan høres $\mathrm{i}$ Sønderjylland i dag, vil jeg gå over til at beskæftige mig med, hvordan mulighederne for at opretholde den sproglige mangfoldighed tegner sig. 
For at skaffe sig indblik i mulighederne for dette må man undersøge, hvordan børn og unge opfatter situationen. Følgende spørgsmål vil være relevante. Holder børn og unge fast ved dialekten? Er de flersprogede? Har de foretaget et skift fra dialekt til rigssprog? Hvad er holdningen til de forskellige former for sprog?

Der er i 1980'erne lavet nogle undersøgelser, der kan give svar på disse spørgsmål. Det drejer sig om Karen Margrethe Pedersens bog: Mødet mellem sprogene i den dansk tyske grænseregion (1986) og min afhandling fra 1981: Findes der dialektbarrierer i Danmark?

\section{Dialektens stilling}

For at skaffe oplysninger om, hvordan skoleelever bedømmer deres eget sprog, lavede jeg i årene 1979-81 en spørgeskemaundersøgelse blandt 537 skoleelever fra hele landet. Heri indgik ialt 177 elever fra Sønderjylland. Alle de sønderjyske dialektområder var repræsenteret. Hovedspørgsmålet lød: Hvordan vil du betegne dit eget sprog? Der var fire svarmuligheder: I dialekt, II rigsdansk, III både dialekt og rigsdansk, IV en blanding af rigsdansk og dialekt. Svarresultatet kom til at se således ud:

I dialekt:

II rigsdansk:

III rigsdansk og dialekt:

IV blanding af rigsdansk og dialekt:
$29 \%$

$12 \%$

$40 \%$

$19 \%$

Det vil altså sige, at ialt $69 \%$ kan tale dialekt, når vi regner gruppe I og III sammen. Dette resultat viser, at dialekten langt fra er ved at forsvinde hos eleverne. Det viste sig for øvrigt, at de sønderjyske elever ligger højere m.h.t. brug af dialekt end alle øvrige landsdele. Nu skal resultatet tages med et vist forbehold, for der er den usikkerhed til stede, at vi ikke helt nøje ved, hvad eleverne forstår ved dialekt. Men betegner man sit sprog som dialekt, kan man i hvert fald gå ud fra, at det afviger fra rigsdansk. At der sikkert i de fleste tilfælde er tale om ægte dialekt, kan man have en begrundet mening om, når man har lyttet til Karen Margrethe Pedersens båndoptagelser med skolebørn i Tinglev. De allerfleste af eleverne demonstrerer, at de kan tale uforfalsket dialekt. Som omtalt afviger elevernes dialekt ikke meget fra tidligere generationers. Når dialekten synes at stå så stærkt hos eleverne, skyldes det naturligvis, at forældre og søskende, deres venner - deres nærmiljø i det hele taget har sønderjysk som omgangssprog. Hvis vi ser på besvarelserne vedrørende forældrenes sprog, fremgår det, at $79 \%$ af forældrene er sønderjysktalende. Der er tale om høje procenter af dialekttalende hos både forældre og børn, 
men det er dog trods alt værd at bemærke, at procenten af dialekttalende børn er lavere end procenten for forældrene. Forskellen er kun 10\%, hvad der kun er lidt, set i sammenligning med andre danske dialektområder. I Vestjylland er der et fald på $20 \%$ fra forældregenerationen til børnene, på Bornholm på næsten 30\%. Tendensen er alle steder klar nok, men afviklingshastigheden er forskellig. Når Sønderjylland adskiller sig fra de andre dialektområder, skyldes det, at dialekten her på grund af de historiske forhold har haft - og stadig har - en højere prestige end andre steder i landet. Når dialekten alligevel står mindre stærkt i de yngste generationer, hænger det næppe sammen med en egentlig nedvurdering af dialekten, men snarere med den almindelige udvikling i samfundslivet. Flere og flere forældre, både i by og på land, er nu til dags udearbejdende, og heraf følger, at flere og flere børn tilbringer en stor del af deres opvækst $\mathrm{i}$ institutioner (vuggestuer, børnehaver, skoler), hvor sproget for det meste er rigsdansk. De yngste generationer, hvis sprog endnu ikke er endegyldigt fastlagt, tilegner sig hurtigt institutionens sprog, og i samme retning påvirkes de af TV og radio. ${ }^{32}$ Skal børnene bevare deres sønderjyske dialekt, kræver det, at de fra forældrenes side stimuleres i at tale dialekt. Karen Margrethe Pedersen stiller spørgsmålet: ${ }^{33}$ »Men hvad nu hvis der ikke er tid og kræfter eller lyst til snak i hjemmet, og børnene og forældrene i det hele taget ikke er så meget sammen til daglig? Hvad nu hvis børnene prioriterer børnehavens, skolens og TV's sprog højere end hjemmets dialekt og måske ligefrem påvirker forældrene sprogligt? Spørgsmålene får lov at stå ubesvarede, men med tosprogede børn har vi ingen garantier for at dialekten bliver videreført. Måske vælger de ikke at tale dialekt med deres børn, når de bliver forældre«.

Rigsdansk, blandingssprog, tosprogede (rigsdansk+dialekt)

Rigdansk tales af 52\% (gruppe I+III) af de udspurgte elever, mens $19 \%$ angiver blandingssprog. Hvordan dette blandingssprog er beskaffent ved vi intet præcist om, sandsynligvis er der i nogle tilfælde tale om et meget rigsdansknært sprog, i andre tilfælde om et meget dialektnært, men det føles i hvert fald af brugerne som forskelligt fra, hvad de forstår ved rigsdansk.

Tosprogede er $40 \%$ af eleverne, de taler altså både dialekt og rigsdansk. Til dem rettedes spørgsmålet: Hvad afgør, hvilket sprog du vælger at tale? Er det den person, du taler med, det sted hvor samtalen foregår, eller er det emnet, der tales om ? Langt de fleste mente, at det forst og fremmest var afhængigt af personen, men også stedet spillede en stor rolle, færre mente at emnet havde nogen særlig indflydelse på sprogvalget. Man taler altså rigsdansk til læreren i skolen, eller mere generelt kan man sige, at rigsdansk anvendes, når man befinder sig uden for sit nærmiljø. Spørgsmålet blev som nævnt kun stillet til de 
tosprogede, men alle grupper har faktisk besvaret spørgsmålet. Dette kunne tyde på, at både de dialekttalende og de blandingssprogstalende nok er »mere tosprogede« end svarene på hovedspørgsmålet lader ane. Men naturligvis kan man - tosproget eller ej - have en mening om, hvornår rigsdansk og hvornår dialekt skønnes mest passende.

\section{Hvordan er vurderingen af og holdningen til dialekt og rigsdansk?}

\section{Dialekt}

Hvordan vurderer eleverne deres dialekt? Mener de, at det at beherske en dialekt er noget værdifuldt, som de nødigt vil opgive? Svarene i min spørgeskemaundersøgelse viser, at de sønderjyske skoleelever er dem, der nødigst vil aflægge deres dialekt til fordel for rigsdansken. De anfører en række argumenter for denne indstilling. De er stolte af deres dialekt, den giver dem en folelse af tilknytning til egnen og lokalmiljøet. De oplever et gruppefællesskab via dialekten. Nogle fremhæver, at det er vigtigt at dialekten bevares, for den er en vigtig faktor $i$ den enkeltes personlige identitet. Aflæggelse af dialekten kan medføre fremmedgørelse i forhold til familie og venner, det kan gøre den enkelte usikker og hæmme ham i at formulere sig frit. Holdningen til dialekten er, som det fremgår, ret følelsesladet.

\section{Rigsdansk}

Hvordan er holdningen til rigsdansk? Ja, de fleste af eleverne anser det primært for vigtigt at beherske rigsdansk, fordi det giver sikkerhed i den personlige fremtræden. Adskillige fremhæver i denne forbindelse, at de har oplevet drillerier på grund af deres dialekt, de har følt sig underlegne og dumme og nervøse for ikke at blive accepteret $i$ et nyt miljø. Der knyttes desuden en række mere specielle kommentarer til rigsdanskbeherskelsen. Det fremhæves, at det er en fordel at kunne tilpasse sit sprog efter situationen. Man kan med rigsdansk blive forstået overalt i landet. Rigsdansk anses for en fordel ved skolestart, skoleskift, eksamen og jobsøgning. Holdningen til rigsdansk er, må man sige, saglig. Her er der ingen følelser involveret.

Hvis de holdninger, der er kommet til udtryk hos eleverne, stadig findes hos den unge generation, og hvis dialekten stimuleres i hjemmiljøet, og hvis den centraliseringstendens, der medførte kommunesammenlægninger, nedlæggelse af de små skoler på landet og oprettelsen af centralskoler samt nedlæggelse af lokale uddannelsesinstitutioner ikke fortsættes, er der vel grund til at mene, at de sønderjyske dialekters forsvinden ikke ligger lige om hjørnet. Men de er truet. 


\section{De sproglige forhold hos det tyske mindretal}

I 1975 udkom der en bog med titlen: Beiträge zur Frage der ethnischen Identifikation des Bundes Deutscher Nordschleswiger (red. Kai Detlev Sievers). Heri behandler Dirk Wilkommen ${ }^{34}$ sprogforholdene hos mindretallet.

Hos det tyske mindretal spiller højtysk naturligvis en stor rolle. Det benyttes som undervisningssprog i de tyske skoler. Det anvendes i kirken, i administrationen af mindretallets organisationer og i forbindelse med kulturelle aktiviteter i det hele taget, altsammen områder, der hører til i det officielle plan. Men gælder det sproget i hjem- og nærmiljø, taler også mindretallet for størstepartens vedkommende sønderjysk. Et rundspørge blandt 315 medlemmer af BDN viste, at $63 \%$ talte sønderjysk, $33 \%$ højtysk og $2 \%$ rigsdansk. De, der har angivet højtysk som hjemmesprog er oftest byboer med højere uddannelse, købmænd, ansatte inden for de liberale erhverv, men for de fleste af dem gælder det, at de også kan tale sønderjysk.

Sønderjysk tales fortrinsvis af landboerne, dvs. landmænd, håndværkere, arbejdere. $\mathrm{Og}$ - oplyses det - de fleste af dem behersker i almindelighed højtysk. Hvad angår mindretallets fastholden ved dialekten, må den tages som udtryk for, at man føler sig knyttet til den region, hvor man er født og opvokset. I kommunikation med sønderjyder, der tilhører flertallet, er dialekten uundværlig, så meget mere som rigsdansk kun beherskes af ganske få inden for mindretallet.

Dirk Wilkommen har beskæftiget sig med aldersfordelingen hos dem, der taler højtysk. Det viser sig, at i den yngre aldersgruppe (20-32 år) ligger andelen af højtysktalende højere end for de ældre. Det tages som udtryk for, at de yngre er på vej væk fra dialekten. Man vælger et »højsprog« frem for en dialekt. Og Dirk Wilkommen giver hertil den kommentar: Hvis dette fravalg af dialekt er mere generelt, kan denne afgørelse også undertiden blive til gunst for rigsdansk i tilfælde af, at tilhørsforholdet til BDN ophører. Men - fortsættes der: »Über eine sprachliche Assimilation der Mitglieder des BDN kann aufgrund des Materials keine sichere Aussage gemacht werden, möglicherweise besteht aber eine Tendenz zur Entscheidung für eine der beiden Hochsprachen als »eigene« Sprache. Eine sprachliche Assimilation (d.h. Übernahme des Rigsdansk als Sprache für alle Bereiche des Lebens) würde eine ethnische Assimilation in erheblichem Masse fördern«.

Hvis vi sammenligner Dirk Wilkommens oplysninger m.h.t. rigsdanskbeherskelse med resultaterne, der fremkom i forbindelse med min undersøgelse af rigdansktilegnelse hos elever i tysk skole i midten af firserne, viser det sig, at eleverne i den tyske skole gennemsnitligt talte et ligeså korrekt rigsdansk som eleverne i den danske skole. Spørgsmålet er så, i hvilket omfang eleverne får 
brug for deres rigsdansk, når de har forladt skolen. Det vil naturligvis afhænge af, hvor mange kontakter de får til rigsdansktalende kredse. Hvad den sønderjyske dialekt angår, fremgår det af Karen Margrethe Pedersens materiale, at den fortsat bruges af eleverne både hjemme og blandt kammerater i skolen samt $\mathrm{i}$ kommunikationen med unge fra flertallet.

\section{Regional identitet og sprog}

Det er en almindelig accepteret opfattelse, at der er sammenhæng mellem sprog og identitet. Gennem sproget placerer man sig i forhold til omverdenen, udsender signaler om, hvilke grupper man henregner sig til. »Sprogbrugen er en uophørlig række af identitetshandlinger«, skriver Inge Lise Pedersen i sin afhandling: Regionalisme og identitet. Om jysk og dansk i tusind år. ${ }^{35}$ Der gøres opmærksom på, at der i de gamle dialektsamfund ikke var nogen tvivl om, at nærmiljøet var vigtigt for identitetsoplevelsen. Til forskel herfra relaterer man sig i dag til større geografiske områder. Hvis man på denne baggrund skal vurdere det regionale sprogs fremtidsmuligheder, må man se på, om »det regionale tilhørsforhold er identitetskabende. Hvis der er mange danskere der mener, at det regionale er er vigtig bestanddel af deres identitet vil det have konsekvenser for dansk talesprog."

Hvis man herudfra vil give sig af med at sige noget om fremtidsmulighederne for sproget i Sønderjylland, må man se på, om der i regionen findes faktorer, som giver betingelser for, at en regional identitet kan opbygges/bevares. Inge Lise Pedersen omtaler ${ }^{36}$ tre faktorer, der er afgørende for regional identitet. (Formålet var her at finde et grundlag for en jysk identitet $\mathrm{i}$ almindelighed.)

1. landsdelen skal have et samlende midtpunkt, en hovedstad.

2. der skal foreligge en rimelig grad af urbanisering, der kan danne grundlag for en bykultur.

3. der skal findes uddannelsesinstitutioner, et universitet, der kan producere højtuddannede jyder med en jysk identitet, en regional elite.

Disse betingelser anses for at være opfyldt nu om dage, når det gælder Jylland som helhed. Århus er hovedstaden, urbaniseringen skrider frem, der findes universitet i Århus, Ålborg og Esbjerg (det sidste producerer dog endnu ikke kandidater). Der skulle på denne baggrund være gode muligheder for udvikling af regional identitet og hermed et jysk regionalsprog.

Men hvordan forholder det sig nu for sønderjydernes vedkommende? Identi- 
ficerer de sig regionalt mere med Jylland i almindelighed end med Sønderjylland i særdeleshed, og - hvis det sidste er tilfældet - har det så indflydelse på sprogudviklingen i regionen?

Det er min opfattelse, at sønderjyder identificerer sig mere med Sønderjylland end med Jylland som helhed. Det kan der være flere årsager til. I hvert fald har landsdelens historie, der jo er forskellig fra de øvrige danske landsdeles, haft betydning. Den frlles kamp for at blive genforenet med Danmark har skabt en stærk regional bevidsthed. Og selv om Genforeningen og det, der gik umiddelbart forud, ligger langt tilbage, er det stadig noget, der har en plads i den sønderjyske bevidsthed. Det kan man bl.a. slutte af, at foreninger som Grænseforeningen og Sprogforeningen stadig er aktive. Desuden er vel også den kendsgerning, at der i området findes et tysk mindretal, medvirkende til, at man ikke glemmer, at man lever i en grænseregion, og hvad det indebærer.

Hvis vi herefter skal se på de tidligere nævnte betingelser for en regional identitet, må der meldes hus forbi m.h.t. en regional hovedstad, men m.h.t. urbanisering ligger Sønderjylland på linje med Nørrejylland. Noget universitet findes ikke i landsdelen, men det er min opfattelse, at seminarierne i Tønder og Haderslev hidtil har spillet en stor rolle, idet mange sønderjyske lærere er blevet uddannet der og valgte at lade sig ansætte i landsdelen. Desuden findes der en institution som Institut for grænseregionsforskning, som bl.a. gennem sin publikation: »Pluk fra forskningen i Sønderjylland « er med til at understøtte den regionale bevidsthed. Publikationer som Sønderjysk Månedsskrift og Sønderjyske Årbøger bør også nævnes i denne forbindelse. Der findes i området også betydelige museer i Sønderborg, Haderslev, Tønder og Åbenrå, regionen har sit eget symfoniorkester, og Radio Syd bringer meget stof fra landsdelen. Jeg kan ikke lade være med at nævne Sønderjysk Allgemeine, en forening, hvis medlemmer består af alle sønderjyske folketingsmedlemmer samt ansatte og journalister på Christiansborg. Noget tilsvarende findes mig bekendt ikke for andre landsdele. Kort sagt, der er rigeligt med betingelser for eksistensen af en regional identitetsfølelse og dermed gode muligheder for udvikling af et sønderjyskpræget regionalsprog som afløser af rigsdansken. Om udviklingen vil gå i den retning $\mathrm{i}$ fremtiden, kan vi ikke vide.

Men det, vi for øjeblikket kan konstatere angående sprogsituationen i landsdelen, er, at dialekten ikke er på fremmarch, den er udelukkende henvist til hjemmet og nærmiljøet, og selv her er den truet. På det officielle plan høres den sjældent. Og ser vi på det sprog, som jeg har omtalt som sønderjysk rigsdansk, ja, så må man om det sige, at lokaltrækkene er få. Der er i hvert fald intet, der i øjeblikket tyder på, at en intern lokalpræget udvikling er i gang. Der er sket det, at Sønderjylland i løbet af de 75 år, der er gået siden Genfor- 
eningen, er blevet så integreret i den almindelige danske udvikling m.h.t. sprogbrug, at man højest kan karakterisere sprogsituationen i Sønderjylland, når det gælder tilbagegang for dialekten, som forsinket i forhold til de øvrige landsdele, lige med undtagelse af Bornholm. M.h.t. rigsdansk ligger området på linje med Jylland og andre dialektområder, og det til trods for at der efter min opfattelse i Sønderjylland eksisterer - og læange har eksisteret - en endog stærk regional identitetsfølelse.

\section{NOTER}

1. G. Johannsen, 1890 , s. 20.

2. H.P. Hanssen, 1890, s. 293.

3. Jeppesen, 1938, s. 21.

4. Anker Jensen, 1900, s. 84-85.

5. Jeppesen, 1938 , s. 9.

6. Werlauff: Det danske Sprog i Hertugdømmet Slesvig, 1819.

7. C. F. Allen: Det danske Sprogs Historie i Hertugdømmet Slesvig eller Sønderjylland, 1857-58.

8. E. Hagerup: Det danske Sprog i Angel, 1854, 2. udg. 1867.

9. J. Kok: Det danske Folkesprog i Sønderjylland, 1863.

10. Nyberg, 1988.

11. Karen Marie Olsen, 1949 , s. 34 .

12. Bjerrum, 1944, s. 461-462.

13. Bjerrum, 1946, s. 212.

14. Gunhild Nielsen, 1990, s. 65.

15. Becker-Christensen, 1984, s. 226.

16. Ravn, 1963, s. 2.

17. Novrup, 1943, s. 33.

18. Ravn, 1963, s. 3.

19. Ravn, 1963 , s. 10.

20. Jeppesen, 1938, s. 40.

21. Jørgensen, 1971, s. 151-156.

22. Jeppesen, 1938, s. 67-70.

23. Bjerrum, 1964, s. 194.

24. Aage Fjalland, 1929, s. 42.

25. Nyberg, 1991, s. 166 og 167.

26. Nyberg 1991, s. 167.

27. Jul Nielsen og Nyberg, 1989.

28. Nikolaj Andersen, 1899, s. 129-183.

28a.Jørgensen, 1930, s. 56-58.

29. Karen Margrethe Pedersen, 1986, s. 70-73, 82-83, 124-127.

30. Karen Margrethe Pedersen, 1986, s. 73.

31. Nissen og Pedersen, 1987, s. 12-14.

32. Karen Margrethe Pedersen, 1986, s. 184.

33. Karen Margrethe Pedersen, 1986, s. 185.

34. Dirk Wilkommen, 1975, s. 133-153.

35. Inge Lise Pedersen, 1993, s. 249.

36. Inge Lise Pedersen, 1993, s. 264. 


\section{LISTE OVER BENYTTET LITTERATUR}

Andersen, Nikolaj: Det danske sprogs indflydelse på höjtysk i Nordslesvig, i; Dania 6. 1899, s. 129183.

Becker-Christensen, Henrik: Dansk mindretalspolitik i Nordslesvig, 1984.

Bjerrum, Anders: Folkemaal og Rigssprog, i: Den danske Bonde (red. N. P. Ejerslev) 1946, s. 189. 214.

Bjerrum, Anders: Om de danske Dialekter i Sønderjylland, i: Sønderjyske Årbøger 1953, s. 101-124. Fjalland, Aage: Vore folkemål i likvidation, i: Danske Folkemaal 1929.

Hanssen-Nørremølle, H.P.: Tysk Gudstjeneste i Nordslesvig, i: Sønderjyske Årbøger 1890, s. $274-$ 293.

Jensen, Anker: Folkemål og Rigsmål i Sønderjylland, i: Dania 7, s. 64-95.

Jensen, Ella: De lange Vokaler i Alsisk, i: Danske Folkemaal, 1979, s. 41-54.

Jensen, Ella og Magda Nyberg: Emmerlevdialekten, 1977.

Jeppesen, Peter: En sønderjysk Dialekts Udvikling. I de sidste generationer (Løgumklosterdialekten) 1938.

Johannsen, Gustav: Nordslesvig i 1889, i: Sønderjyske Årbøger 1890, s. 1-20.

Jørgensen, Peter: Nogle bemærkninger om undersøgelsen af det højtyske sprog i Slesvig, i: Danske Folkemaal 1930-31, s. 56-60.

Jørgensen, Peter: En sønderjysk hilsen, i: Dansk Dialektologi og Sproghistorie 1971, s. 151-156.

Kristensen, Marius: Sproget gennem Tiderne, i: Sønderjyllands Historie fremstillet for det danske Folk, 1930, I., s. 51-101.

Kristensen, Marius: De sønderjyske købstadsmål, i: Festskrift til H. P. Hanssen på hans 70-Aarsdag den 21. Februar 1932, s. 342-345.

Nielsen, Bent Jul og Magda Nyberg: Talesprogsvariationen i Odder kommune.

I. Lokalsprog i sociolingvistisk belysning, i: Danske Folkemål 1992, s. 45-202.

II. Yngre og ældre rigsmålsformer i sociolingvistisk belysning, i: Danske Folkemål 1993, s. 249-348.

Nielsen, Gunhild: Et særtræk i Tønders gamle købstadsmål, i: Danske Folkemål 1990, s. 62-70.

Nissen, Hans Jürgen og Karen Margrethe Pedersen: German primary and lower secondary minority education in Sønderjylland/Nordschleswig, Denmark, 1987.

Novrup, Hans: Folkeskolen i de sønderjyske Landsdele, i: Kulturelle forhold i Sønderjylland 19201942 (red. Jacob Petersen) 1942, s. 1-48.

Nyberg, Magda: Undersøgelser ved den dansk-tyske grænse efter 1945. i: Danske Folkemål 1978, s. 82-91.

Nyberg, Magda: Dialekt og rigsmål i skolen, i: Danske Folkemål 1979, s. 1-40.

Nyberg, Magda: Findes der dialektbarrierer i Danmark (II), i: Danske Folkemål, s. 69-130.

Nyberg, Magda: Tyske låneord i sønderjysk. i: Dialektstudier 5. 1988.

Nyberg, Magda: Unge sønderjyders rigsmålstilegnelse, i: Danske Folkemål 1991, s. 159-168.

Pedersen, Karen Margrethe: Dialekt, regionalsprog, rigssprog, en analyse af børns skolesprog, 1977.

Pedersen, Karen Margrethe: Mojn - en hilsen i Sønderjylland i 75 år, i: Grænsen i 75 år 1920-1995, Institut for Grænseregionsforskning 1995, s. 244-267 (fremkommet efter affattelse af nærværende artikel).

Pedersen, Karen Margrethe: Mødet mellem sprogene i den dansk-tyske grænseregion, 1986.

Pedersen, Inge Lise: Regionalisme og identitet. Om jysk og dansk i tusind år, i: Jyske Studier 1993, s. 249-272.

Ravn, L.S.: Tyskuddannede lærere ved danske kommunale skoler i Sønderjylland, 1920-63, 1963.

Wilkommen, Dirk: Zur Stellung der Kommunikation bei den Mitgliedern des Bundes Deutscher

Nordschleswiger, i: Beiträge zur Frage der ethnischen Identifikation des Bundes Deutscher

Nordschleswiger (red. Kai Dilev Sievers) 1975, s. 133-153. 
